\title{
Effects of HACCP System Implementation on Domestic Livestock Product Plants
}

\author{
Seung Hee Baek ${ }^{1}$, Soo Cheol Kang ${ }^{1}$, Won Cheol Lee ${ }^{1,2}$, and In Sik Nam ${ }^{1 *}$ \\ ${ }^{1}$ Korea Livestock Products HACCP Accreditation Service, Anyang 430-731, Korea \\ ${ }^{2}$ Department of Biotechnology, Hankyong National University, Ansung 456-749, Korea
}

\begin{abstract}
The objective of this study was to investigate the problems and benefits associated with the implementation of HACCP on livestock product of plants in Korea. The survey was carried out by randomly selecting 115 HACCP accredited meat processing plants, all across the country. A total of 105 complete responses were selected for analysis. The results were as follows: approximately $60 \%$ of the respondents employed less than twenty workers. The average period of operating HACCP system was 3.4 years. The respondents replied that the major incentive to implement the HACCP system was to improve hygiene management ability. More than half of the respondents $(59.05 \%)$ claimed that the implementation of the HACCP system cost less than 400 million won, and the highest investment in terms of cost was the freezer/refrigerator . In the preparation period taken to implement the HACCP system, the 6-12 mon category had the highest percentage (55.24\%). Most respondents replied that there was an increase in the customer satisfaction, plant image and turnover, after HACCP implementation $(p<0.05)$. A total of $98.09 \%$ of respondents had the opinion that their plant workers had improved in their understanding of food hygiene by HACCP implementation $(p<0.05)$. Approximately $79 \%$ of respondents indicated that customer complaints decreased, as a result of HACCP implementation.
\end{abstract}

Key words: HACCP, implementation, livestock product plants, survey

\section{Introduction}

Hazard Analysis Critical Control Point (HACCP) is a management system to control biological, chemical, and physical risks that may result from growing, harvesting, processing, manufacturing, transporting and distributing, or preparation and consumption of manufactured food. The goal of implementing HACCP is to manage potential hazards through risk assessment during food production with a focus on prevention rather than end product testing (Kwak, 1999; Unnevehr and Jenson, 1996). The HACCP becomes one of the best tools for preventing and reducing biological, physical and chemical hazards from food or foodstuffs to acceptable levels (Lee et al., 2010, Lee et al., 2011; Nam et al., 2008).

In Korea, the hygiene and safety of livestock products has become a major issue of concern. In several countries, including Korea, HACCP system has been introduced with regard to product hygiene and safety.

*Corresponding author: In Sik Nam, Korea Livestock Products HACCP Accreditation Service, Anyang 430-731, Korea. Tel: 8231-390-5269, Fax: 82-31-465-6217, E-mail: nis08@ihaccp.or.kr
The HACCP system including Sanitary Standard Operation Procedure (SSOP), and Good Manufacturing Practice (GMP) was established to comply with the Livestock Products Processing Act (LPPA) in 1997 (Lee, 2007). It was first introduced to slaughterhouses and livestock product plants. After that the system was extended, according to the plan of Ministry for Food, Agriculture, Forestry and Fisheries (MIFAFF) in Korea, to raw milk collection, the keeping and transportation of livestock products, meat retailers and animal farms by yearly plan. In 2006, Korea Livestock Products HACCP Accreditation Service (KOLPHAS) was established to activate HACCP system implementation in livestock industry. The roles of KOLPHAS are designation and control of HACCP from the farm to the consumption stage, namely farm, feed factory, milk depot, processing, transport, keeping, and retailer.

Total number of livestock product plants in 2009 is approximately 2,757 plants in Korea. In the area of livestock product plants, most developed countries including USA (1998), EU( 1996) and Australia (1997) are implementing HACCP system as an obligation. In Korea, HACCP implementation of the slaughter house is only 
compulsory. The HACCP system was implemented on meat processing plant in 1997, slaughter house in 2000 , livestock product plant in 2001, milk processing plant, meat sale and distribution in 2004, feed mill in 2005, and animal farm in 2006 (Animal, Plant and Fisheries Quarantine and Inspection Agency, 2010)

The studies on HACCP have recently focused on evaluation of sanitation management performance, benefits of HACCP implementation, and employees' knowledge and performance degree of HACCP in school foodservice sector (Kim and Lee, 2008; Moon and Ryu, 2004; Park and Park, 2009).

In the livestock products sector, economic feasibility of HACCP at slaughter house (Kwak et al., 2002), productivity analysis of HACCP implemented pig farms (Nam et al., 2008), and comparative analysis of the prerequisite items for HACCP in livestock product plants (Hong and Cho, 2008) have been reported. However, there have not yet been studied about the basic information for implementation and advantages of HACCP in the livestock products sector.

Therefore, the aims of this study were to determine factors affecting HACCP implementation, and to investigate the effect of HACCP implementation on domestic livestock product plants.

\section{Material and methods}

\section{Survey}

In this study, a survey was conducted with subjects to operate HACCP in livestock product plants during the period July 1 to December 5, 2008. A self-administered questionnaire was distributed in person by the researchers. The survey was carried out at 115 livestock product plants located in all around of Korea (Table 1). Most of the respondents were heads of quality control departments, and all of respondents claimed that they operated HACCP system in plants.

\section{Questionnaire}

The survey questionnaire was prepared and modified according to the results of related studies (Bai et al., 2007; George and George, 1999; Spencer et al., 1999). The questionnaire sought information about the general characteristics of the subjects and effect of the HACCP system implementation. A total of 115 questionnaires were distributed, and 105 respondents completed the survey with an overall response rate of $91.34 \%$. The survey instrument consisted of 3 parts. In part 1 ( 4 of 16 questions),
Table 1. Location of respondents participated in the survey of livestock product plants that implemented HACCP system

\begin{tabular}{lrr}
\hline \hline Location & $\mathrm{N}^{1)}$ & \multicolumn{1}{c}{$\%$} \\
\hline Seoul & 7 & 6.09 \\
Gyunggi & 21 & 18.26 \\
Kangwon & 9 & 7.82 \\
Gyeongbuk & 15 & 13.05 \\
Gyeongnam & 18 & 15.65 \\
Chungbuk & 7 & 6.09 \\
Chungnam & 11 & 9.56 \\
Jeonbuk & 11 & 9.56 \\
Jeonnam & 9 & 7.83 \\
Jeju & 7 & 6.09 \\
\hline${ }^{1)} \mathrm{N}=115$ & &
\end{tabular}

we asked the general characteristics of subjects' plant, such as period of HACCP operating, number of employees, annual turnover, and whether other accreditations had been adopted (Table 2). Part 2 contained 6 questions related to factors that may affect HACCP implementation (Table 3-Table 7). In part 3, 105 respondents were divided into four groups according to the number of employees as shown in Table 2. This part consisted of 6 questions related to benefits and effects of HACCP implementation (Table 8-Table 13).

\section{Statistical analysis}

The questionnaire responses were analyzed using SPSS 12.0 for Windows (Version 12.0 software, 2004, SPSS, Inc., Chicago, IL). To examine the relationship among the variables, the chi-square test was used, and the level of statistical significance was $p<0.05$.

\section{Results and Discussion}

\section{General characteristics}

Table 2 shows the general information of each subdivided livestock product plants. The average years of operating HACCP system was 3.4 years. The highest was 3-4 years $(34.29 \%)$, whereas less than 1 year was the lowest $(8.57 \%)$. Approximately $60 \%$ of the respondents employed less than twenty workers and/or had a turnover of less than 7 billion won. We also asked respondents whether they had implemented any other accreditation. A total of $25(23.81 \%)$ among the 105 respondents claimed that they had other quality management systems such as Korea Food \& Drug Administration (KFDA) HACCP, Good Manufacturing Practice (GMP), International Standardization Organization (ISO) series, and domestic quality 
Table 2. General information respondents participated in the survey for HACCP system implemented livestock product plants

\begin{tabular}{|c|c|c|c|}
\hline \multicolumn{2}{|c|}{ General characteristics of respondents ${ }^{1)}$} & $\mathrm{N}$ & $\%$ \\
\hline \multirow{5}{*}{$\begin{array}{c}\text { Total operation } \\
\text { period of HACCP }\end{array}$} & 1 years & 9 & 8.57 \\
\hline & 2 years & 33 & 31.43 \\
\hline & 3-4 years & 36 & 34.29 \\
\hline & $5-7$ years & 27 & 25.71 \\
\hline & Total & 105 & 100 \\
\hline \multirow{5}{*}{$\begin{array}{l}\text { Number of } \\
\text { employees }\end{array}$} & less than 10 & 35 & 33.33 \\
\hline & 10 to 20 & 31 & 29.52 \\
\hline & 21 to 50 & 25 & 23.81 \\
\hline & more than 50 & 14 & 13.33 \\
\hline & Total & 105 & 100 \\
\hline \multirow{5}{*}{$\begin{array}{l}\text { Annual turnover } \\
\text { (billion won) }\end{array}$} & less than 3 & 35 & 33.33 \\
\hline & 3 to 7 & 26 & 24.76 \\
\hline & 7 to 12 & 20 & 19.05 \\
\hline & more than 12 & 24 & 22.86 \\
\hline & Total & 105 & 100 \\
\hline \multirow{5}{*}{$\begin{array}{l}\text { Other accredita- } \\
\text { tions implemented }\end{array}$} & $\mathrm{KFDA}^{2)}-\mathrm{HACCP}^{3)}$ & 4 & 3.81 \\
\hline & $\mathrm{ISO}^{4)}$ series & 13 & 12.38 \\
\hline & $\begin{array}{l}\text { Domestic quality certifica- } \\
\text { tion system }\end{array}$ & 8 & 7.62 \\
\hline & Not implemented & 80 & 76.19 \\
\hline & Total & 105 & 100 \\
\hline
\end{tabular}

${ }^{1)}$ Period of survey: July 1, 2008 to December 5, 2008

${ }^{2}$ KFDA: Korean Food and Drug Administration

${ }^{3)}$ HACCP: Hazard Analysis and Critical Control Point

${ }^{4)}$ ISO: International Standardization Organization

certification systems (e. g. G-mark certification).

\section{HACCP system implementation}

Table 3 shows the reasons for the implementation of the HACCP system. The main incentive of respondents was to improve hygiene management ability (34.74\%), followed by the improvement of customer confidence $(24.88 \%)$, recommendation by trade organization (15.49\%), and the increase of product sales (15.49\%). Respondents attributed much more importance to improved hygiene management ability rather than the increase in turnover. In contrast, a comparable study by Anastasios and Achilleas (2007) evaluated the incentives of HACCP implementation of food enterprises and reported that the major incentive among respondents was to provide them with more chances to improve production procedures rather than to improve product quality. In other words, they were implemented HACCP system as a way of improving their profit. Madonado et al. (2005) and Henson et al. (1999) reported that the major benefit of implementing HACCP in the Mexican meat industry and the UK milk processing
Table 3. Purpose of implementing HACCP system to the respondent's livestock product plants

\begin{tabular}{lcc}
\hline \hline \multicolumn{1}{c}{ Incentives } & $\mathrm{N}$ & \multicolumn{1}{c}{$\%$} \\
\hline To recommend trade organization & 33 & 15.49 \\
To improve hygiene management ability & 74 & 34.74 \\
To improve customer confidence (satisfaction) & 53 & 24.88 \\
To increase product sales & 33 & 15.49 \\
To reduce customer complaints, Reduces the & 17 & 7.98 \\
$\quad$ number of claims & & \\
Unknown & 3 & 1.41
\end{tabular}

A respondent $(\mathrm{n}=105)$ have indicated more than one type.

industry were to reduce product wastage. Compared to other countries, our results suggest that Korean livestock product plants were more likely to implement HACCP to improve hygiene ability rather than for other reasons. This result might be related with some reasons. First, Korean consumers showed increased the knowledge about food hygiene result from bovine spongiform encephalopathy (BSE), foot and mouth disease (FMD), and Bird Influenza etc. Second, food hygiene might be the most important factors for livestock product plants employers and employees because SSOP was compulsorily applied for livestock products processing plant.

As for the cost of HACCP implementation, two hundred million won to less than four hundred million won was the highest $(25.71 \%)$ and less than one hundred million won was the lowest at $15.24 \%$. More than half of respondents $(53.33 \%)$ spent one million won to less than ten million won for annual HACCP operating cost, and the average cost was three hundred fourteen million won in all respondents (Table 4). As a result, we found that total

Table 4. HACCP set-up or annual HACCP operating cost (Property, plant, and equipment expenditures) required to comply with HACCP

\begin{tabular}{clrr}
\hline \hline & Million won & N & $\%$ \\
\hline & less than 100 & 16 & 15.24 \\
& 100 to 200 & 19 & 18.10 \\
HACCP imple- & 200 to 400 & 27 & 25.71 \\
mentation cost & 400 to 800 & 17 & 16.19 \\
& 800 to 3,000 & 17 & 16.19 \\
& Unknown & 9 & 8.57 \\
\cline { 2 - 4 } & \multicolumn{1}{c}{ Total } & 105 & 100 \\
\hline \multirow{3}{*}{ Annual HACCP } & less than 1 & 2 & 1.90 \\
& 1 to 5 & 25 & 23.81 \\
& 5 to 10 & 29 & 27.62 \\
& 10 to 30 & 31 & 29.52 \\
& 30 to 50 & 7 & 6.67 \\
& more than 50 & 11 & 10.48 \\
\cline { 2 - 4 } Totion cost & Total & 105 & 100 \\
\hline
\end{tabular}


livestock product industry investment amounted to about 380 million in HACCP-required investments.

As the individual costs of operating HACCP in their plant (Table 5), $68.57 \%$ of respondents presented freezer /refrigerator to be the highest invest cost associated with the implementation of HACCP. However, other respondents indicated sanitation equipment (8.57\%), floor and ceiling (8.57\%), or Heating, Ventilation, and Air Conditioning (HVAC) system (6.67\%).

The majority of the respondents $(89.44 \%)$ claimed that they had used an external consultant to develop their HACCP system (data not shown). This result was consistent with the study by Anastasios and Achilleas. (2007). They reported that 74 of 83 companies $(89.2 \%)$ which have a quality assurance system, such as HACCP and/or

Table 5. Rank of cost for equipment and facilities of HACCP implemented livestock product plants

\begin{tabular}{lrc}
\hline \multicolumn{1}{c}{ Contents } & $\mathrm{N}$ & $\%$ \\
\hline Freezer/refrigerator & 72 & 68.57 \\
HVAC system $^{1)}$ & 7 & 6.67 \\
Sanitation equipment & 9 & 8.57 \\
Measure utensil & 4 & 3.81 \\
Floor, ceiling & 9 & 8.57 \\
Expert employment & 3 & 2.86 \\
Wall & 1 & 0.95 \\
\hline \multicolumn{1}{c}{ Total } & 105 & 100 \\
\hline
\end{tabular}

${ }^{1)}$ An HVAC (Heating, Ventilation, and Air Conditioning) system is designed to control temperature, humidity, purity, and distribution of conditioned air throughout a plant.

Table 6. Main point used external consultant in the HACCP system implementation ${ }^{1)}$

\begin{tabular}{lcc}
\hline \hline \multicolumn{1}{c}{ Contents } & $\mathrm{N}$ & $\%$ \\
\hline Plant schematic & 23 & 11.06 \\
Facility construction & 27 & 12.98 \\
Standard guideline & 62 & 29.81 \\
Manager training & 39 & 18.75 \\
Record keeping & 28 & 13.46 \\
Affairs administration & 8 & 3.85 \\
Above all & 21 & 10.10 \\
\hline
\end{tabular}

${ }^{1)} \mathrm{n}=94$ respondents who said they had used external consultant A respondent have indicated more than one type.
ISO series, used an external consultant to develop their HACCP system. This result reflects how important the role of the external consultants in the HACCP implementation is. Table 6 presents a list of 7 types of consultancy services and we asked respondents to rank these according to their importance in HACCP implementation in their plant (A respondent was permitted to indicate more than one type).The respondents claimed that the most important contents during the development of the HACCP system was to make standard guideline (29.81\%), and the second most important contents was to manager training (18.75\%).

In the period taken to implement the HACCP system, the category 6-12 mon had the highest percentage (approximately 64\%) among the respondents, while the lowest period category was less than 6 mon (9\%).

\section{Effects of HACCP system implementation}

In part 3, we asked respondents 6 questions related to the effect of HACCP implementation (Table 8-11). The respondents were divided into four groups by the number of employees, and a chi-square test was employed to compare the characteristics of the four groups. Table 7 shows the effect of adopting HACCP for the livestock product plants. $80.95 \%$ of the respondents replied that the plants themselves were developed throughout operating the HACCP system, with only $1.91 \%$ claiming no effect. Although there was no significant difference in the effect of HACCP adoption, plants of less than 10 employees was highest, and over 50 employees was lowest. Table 9 found that $91.43 \%$ of all respondents claimed that there was an increase in customer satisfaction after HACCP

Table 7. Preparatory periods for implementing HACCP system

\begin{tabular}{lrr}
\hline \multicolumn{1}{c}{ Periods } & N & \multicolumn{1}{c}{$\%$} \\
\hline Less than 6 mon & 9 & 8.57 \\
6-12 mon & 58 & 55.24 \\
12-24 mon & 28 & 26.67 \\
More than 24 mon & 10 & 9.52 \\
\hline \multicolumn{1}{c}{ Total } & 105 & 100 \\
\hline
\end{tabular}

Table 8. HACCP system implementation was contributed to develop our plant

\begin{tabular}{|c|c|c|c|c|c|c|c|}
\hline Number of employees & Yes (\%) & A little (\%) & No (\%) & Total (n) & $\chi^{2}$ & $\overline{d f}$ & $\overline{p p}$ \\
\hline$<10$ & $30(85.71)$ & $4(11.43)$ & $1(2.86)$ & 35 & & & \\
\hline 10 to 20 & $23(74.19)$ & $8(25.81)$ & $0(0)$ & 31 & & & \\
\hline 21 to 50 & $19(79.17)$ & $4(16.67)$ & $1(4.17)$ & 24 & 4.185 & 6 & 0.652 \\
\hline$>50$ & $13(86.67)$ & $2(13.33)$ & $0(0)$ & 15 & & & \\
\hline Total & $85(80.95)$ & $18(17.14)$ & $2(1.91)$ & 105 & & & \\
\hline
\end{tabular}


implementation, whereas only $8.57 \%$ of respondents claimed that implementation of HACCP had no relation to customer satisfaction in their plants. Chi-square test showed that the fewer number of employees significantly affected to the HACCP system adoption $(p<0.05)$. The proportion indicating "increase" was $73.33 \%$ and for "a little increase" $18.10 \%$ of all respondents. In this respect, the survey result identified that $81.90 \%$ respondents (16.19\% strongly agreed and $44.76 \%$ completely agreed) believed that sales was increased by HACCP implementation (Table 12). It was found that $98.09 \%$ of all respondents had the opinion that their plant workers had an improvement in their understanding of food hygiene by implementation of HACCP in Table $10(p<0.05)$. This finding was consistent with result of Table 3 . In other words, the most important purpose of HACCP implementation for survey respondents was to improve hygiene management ability. Interestingly, the relative large size livestock product plants ( $>21$ employees) respondents who claimed implementation of HACCP had not related to customer satisfaction and knowledge of hygiene of employees was significantly higher than those of the relative small size ones $(<20$ employees) $(p<0.05)$. Indeed, most of the relatively large sized livestock product plants were operating other food safety/quality management systems, such as GMP/SSOP, ISO series, and domestic quality certification system (data not shown). Thus, this result means that customer satisfaction and knowledge of hygiene of employees had already been improved by food safety/quality management systems. When respondents were asked whether their plant image was improved by HACCP implementation (Table 11), 94.29\% agreed. Table 12 found that $81.90 \%$ of the all respondents claimed that their plant had increased turnover as a result of imple-

Table 9. Changes of customer satisfaction after implementing HACCP system

\begin{tabular}{|c|c|c|c|c|c|c|c|}
\hline Number of employees & Yes (\%) & A little (\%) & No (\%) & Total (n) & $\chi^{2}$ & $\mathrm{df}$ & $\overline{p p}$ \\
\hline$<10$ & $28(80.00)$ & $7(20.00)$ & $0(0)$ & 35 & & & \\
\hline 10 to 20 & $26(83.87)$ & $5(16.13)$ & $0(0)$ & 31 & & & \\
\hline 21 to 50 & $14(58.33)$ & $5(20.83)$ & $5(4.76)$ & 24 & 17.803 & 6 & 0.007 \\
\hline$>50$ & $9(60.00)$ & $2(13.33)$ & $4(3.81)$ & 15 & & & \\
\hline Total & $77(73.33)$ & $19(18.10)$ & $9(8.57)$ & 105 & & & \\
\hline
\end{tabular}

Table 10. Changes of improvement of understanding hygiene and food safety after implementing HACCP system

\begin{tabular}{|c|c|c|c|c|c|c|c|}
\hline Number of employees & Yes (\%) & A little (\%) & No (\%) & Total (n) & $\chi^{2}$ & df & $\overline{p p}$ \\
\hline$<10$ & $33(94.29)$ & $2(5.71)$ & $0(0)$ & 35 & & & \\
\hline 10 to 20 & $30(96.77)$ & $1(3.23)$ & $0(0)$ & 31 & & & \\
\hline 21 to 50 & $23(95.83)$ & $1(4.17)$ & $0(0)$ & 24 & 12.697 & 6 & 0.048 \\
\hline$>50$ & $12(80.00)$ & $1(6.67)$ & $2(13.33)$ & 15 & & & \\
\hline Total & $98(93.33)$ & $5(4.76)$ & $2(1.91)$ & 105 & & & \\
\hline
\end{tabular}

Table 11. Image changes after HACCP system implementation

\begin{tabular}{|c|c|c|c|c|c|c|c|}
\hline Number of employees & Yes $(\%)$ & A little (\%) & No $(\%)$ & Total (n) & $\chi^{2}$ & $\mathrm{df}$ & $p$ \\
\hline$<10$ & $20(57.14)$ & $13(37.14)$ & $2(5.72)$ & 35 & & & \\
\hline 10 to 20 & $22(70.97)$ & $7(22.58)$ & $2(6.45)$ & 31 & & & \\
\hline 21 to 50 & $18(75.00)$ & $4(16.67)$ & $2(8.33)$ & 24 & 4.595 & 6 & 0.597 \\
\hline$>50$ & $11(73.33)$ & $4(26.67)$ & $0(0)$ & 15 & & & \\
\hline Total & $71(67.62)$ & $28(26.67)$ & $6(5.71)$ & 105 & & & \\
\hline
\end{tabular}

Table 12. Changes of turnover after HACCP system implementation

\begin{tabular}{|c|c|c|c|c|c|c|c|c|c|}
\hline $\begin{array}{l}\text { Number of } \\
\text { employees }\end{array}$ & Increase & A little & No relation & A little & Decrease & $\begin{array}{l}\text { Total } \\
\text { (n) }\end{array}$ & $\chi^{2}$ & $\mathrm{df}$ & $p$ \\
\hline$<10$ & $5(14.29)$ & $26(74.29)$ & $2(5.71)$ & $1(2.86)$ & $1(2.86)$ & 35 & & & \\
\hline 10 to 20 & $16(51.61)$ & $10(32.26)$ & $2(6.45)$ & $3(9.67)$ & $0(0)$ & 31 & & & \\
\hline 21 to 50 & $12(50.00)$ & $7(29.17)$ & $3(12.51)$ & $2(8.33)$ & $0(0)$ & 24 & 25.147 & 12 & 0.014 \\
\hline$>50$ & $6(40.00)$ & $4(26.67)$ & $3(20.00)$ & $1(6.67)$ & $1(6.67)$ & 15 & & & \\
\hline Total & $39(37.14)$ & $47(44.76)$ & $10(9.53)$ & $7(6.67)$ & $2(1.90)$ & 105 & & & \\
\hline
\end{tabular}


Table 13. The rate of customer complaint after HACCP system implementation

\begin{tabular}{|c|c|c|c|c|c|c|c|c|c|}
\hline $\begin{array}{l}\text { Number of } \\
\text { employees }\end{array}$ & Increase & A little & No relation & A little & Decrease & $\begin{array}{c}\text { Total } \\
\text { (n) }\end{array}$ & $\chi^{2}$ & $\mathrm{df}$ & $p$ \\
\hline$<10$ & $1(2.86)$ & $1(2.86)$ & $2(5.71)$ & $13(37.14)$ & $18(51.43)$ & 35 & & & \\
\hline 10 to 20 & $0(0)$ & $2(6.45)$ & $6(19.35)$ & $12(38.72)$ & $11(35.48)$ & 31 & & & \\
\hline 21 to 50 & $1(4.17)$ & $3(12.50)$ & $2(8.33)$ & $8(33.33)$ & $10(41.67)$ & 24 & 11.006 & 12 & 0.528 \\
\hline$>50$ & $0(0)$ & $0(0)$ & $4(26.67)$ & $5(33.33)$ & $6(40.00)$ & 15 & & & \\
\hline Total & $2(1.91)$ & $6(5.71)$ & $14(13.33)$ & $38(36.19)$ & $45(42.86)$ & 105 & & & \\
\hline
\end{tabular}

menting HACCP, especially those plants with less than 10 employees, which was the highest in each group, $36.05 \%$ (31 of 86 respondents claimed an "increase" or "a little increase") $(p<0.05)$. Respondents were asked that whether HACCP implementation increased or decreased customer complaints at their plants (Table 13) and 79.05\% indicated a decrease resulting from HACCP implementation.

In conclusion, implementation of HACCP system on livestock product plants can be used to increase livestock product safety by understanding food hygiene of plant workers and increasing the rate of sale. Further study was required to investigate the rate of biological contamination, e.g. with Escherichia coli and Salmonella spp., before and after HACCP system implementation on livestock product plants in the future.

\section{References}

1. Anastasios, S. and Achilleas, K. (2007) HACCP implementation in northern Greece: Food companies' perception of costs and benefits. Br. Food J. 109, 5-19.

2. Animal, Plant and Fisheries Quarantine and Inspection Agency (2010). Available: http://www:qia.go.kr/livestock/clean/livestock livestock_food.jsp.

3. Bai, L., Ma, C. L., Yang, Y. S., Zhao, S. K., and Gong, S. L. (2007) Implementation of HACCP system in China: A survey of food enterprises involved. Food Control 18, 11081112.

4. George, M. and George, T. (1999) HACCP: Implementation in Greek industry. Qual. Reliab. Engng. Int. 15, 385-396.

5. Henson, S., Holt, G., and Northen, J. (1999) Costs and benefits of implementing HACCP in the UK dairy processing sector. Food Control 10, 99-106.

6. Hong, C. H. and Cho, D. H. (2008) Comparative analysis of the prerequisite items applicable to the HACCP in livestock processing plants. J. Food Hyg. Safety 23, 19-25.

7. Kim, G. M. and Lee, S. Y. (2008) A study on the sanitation management status and barriers to HACCP system implementation of school foodservice institutions in Seoul metropolitan area. J. Comm. Nutr. 13, 405-417.

8. Kwak, C. K., Kim, T. K., Park, S. H., and Jang, J. K. (2002)
Economic feasibility of HACCP at slaughter plants. Korean. J. Agric. Econ. 29, 1-18.

9. Kwak. T. K. (1999) Implementation of HACCP to the foodservice industry and HACCP plan development. Food Ind. Nutr. 4, 1-13.

10. Lee, B. O. (2007) The structure and characteristics of HACCP system for livestock products in Korea. Korean. J. Agric. Econ. 34, 456-472.

11. Lee, G. Y., Lee, J. Y., Back, S. H., Hwang, I. J., Lee, K. S., Kim, Y. S., Kim, B. H., Kim, H. S., Kang, S. C., Cho, J. J., Park, M. S., Suk, H. J., and Nam, I. S. (2011) Study on the management level of pathogenic bacteria in HACCP system implemented animal farms. Korean J. Anim. Sci. Technol. 53, 67-74.

12. Lee, J. Y., Paik, J. K., Whang, H .S., Lee, J. E., Shin, W. S., Kim, H. W., Paik, H. D., and Hong, W. S. (2010) Survey of hygienic condition and management of meat markets in Seoul and Gyung-gi area, Korea (HACCP-certified and non certified). Korean J. Food Sci. Ani. Resour. 30, 336-344.

13. Maldonado, E. S., Henson, S. J. Caswell, J. A., Leos, L. A., Martinez, P. A., Aranda, G., and Cadena, J. A. (2005) Costbenefit analysis of HACCP implementation in the Mexican meat industry. Food Control 16, 375-381.

14. Moon, H. K. and Ryu, K. (2004) Usage status survey on some essential facilities, equipment and documentary records for HACCP implementation in contract foodservice $J$. Korean Soc. Food Sci. Nutr. 33, 1162-1168.

15. Nam, I. S. Cho, J. J., Kim, H. S., Kim, J. M., Lim, D. K., Kim, J. N., Pyo, S. I., Kim, T. J., and Kwak, H. K. (2008) Effects of HACCP system implementation on productivity of swine farm. Korean. J. Vet. Publ. Hlth. 32, 245-250.

16. Park, J. S. and Park, S. I. (2009) A survey of washing and sanitizing methods for the pre-preparation of fruits at a school foodservice in the Seoul and Kyunggi area. Korean $J$. Food Culture 24, 39-50.

17. Spencer, H., Georgina, H., and James, N. (1999) Costs and benefits of implementing HACCP in the UK dairy processing sector. Food Control 10, 99-106.

18. Unnevehr, L. J. and Jensen, H. H. (1996) HACCP as a regulatory innovation to improve food safety in the meat industry. Am. J. Agric. Econ. 78, 764-769.

(Received 2011.8.26/Revised 1st 2012.1.27, 2nd 2012.3.30/ Accepted 2012.3.31) 